\title{
Advancing Academic English Teaching and Learning in China: A Meta-analysis
}

\author{
Huijuan Wang \\ Department of Foreign Languages, Northwest A\&F University, China \\ Yufeng Zou \\ Department of Foreign Languages, Northwest A\&F University, China
}

\begin{abstract}
Learning Academic English (AE) has been gaining importance day by day globally but China is still lagging behind in this race of Academic English learning and teaching. China is behind the world in teaching and learning English due to many problems that have been creating challenges for Chinese students. This study used the meta-analysis approach to identify the challenges created by the poor academic teaching and learning and the possible solutions to eliminate these challenges. The study uses the correlation and regression analysis to identify the impact of poor English teaching facilities, worse intelligibility, grammatical issues, poor communication skills, and language complexity on the challenges faced by the Chinese students. After the identification of the challenges, policy recommendations have been made based on the qualitative data analysis of the previous studies.
\end{abstract}

Index Terms - Chinese students, Academic English teaching, Academic English learning, meta-analysis, worse intelligibility, grammatical issues, poor communication skills, language complexity, challenges

\section{INTRODUCTION}

\section{Background}

Learning English as an academic language and in general has become important these days as English is the world's second most spoken language (McKay, 2002). However, Chinese people are still having problems in learning AE language. The AE language impacts their learning level in terms of test design, textbooks in China, curriculum design and teaching methods. All these ideas and designs are borrowed from the USA and UK due to Chinese not fulfilling the requirements in terms of linguistic context (Chen, 2015). Both personal and macro-level factors are the main contributors for this problem. In addition to this, the reason also lies in the less practice and problems arising in listening and speaking English. According to Crystal (2012), before 1980, the importance of English as an academic language was low and it was not considered as the global language. After 1980, the importance of AE language was in a increasing trend and it was considered as the global language (Pan and Block, 2011). It has become essential for students to learn AE as most of the learning material on website and in books are given in the English language.

This world of global commerce, IT, banking, and marketing industries linguistically are dominated by the English globally regardless of the development and protection of local culture, identities, and language. According to Arrighi (2007), China has now become a dominant economic power, so, it is now equally important to evaluate the Chinese people thinking about the AE language learning and teaching in China. However, Chinese traditional teaching methods are not reliable to provide an optimal solution to learn AE. In this study, firstly the current status of $\mathrm{AE}$ teaching methods and learning level is discussed. In the end, it is recommended to use effective AE teaching methods which will make it easy to listen and learn the AE language. Moreover, all methods are taken from previous studies to evaluate which method is best for English language teaching and learning. The methods involve steps to follow such as teaching $\mathrm{AE}$ writing and reading, teaching English as a cultural value and teaching listening and oral skills in general. This study is an attempt to investigate the reasons behind the limitations of teaching and learning AE as an academic language for Chinese students. After analyzing the extensive literature, case studies, and papers, this study aims at building a model of different styles and features to promote the teaching and learning of AE for Chinese students.

Problem Statement

The problems are: the current status of AE language Learning in China; the standards of AE language learning and teaching at the academic level and the effect of above-mentioned findings on the choice of English norms.

Research Questions

- What is the status and problem of academic English teaching and learning in China?

- How do previous studies deal with these problems?

- What measures does this paper suggest for academic English teaching and learning in China?

Research objectives

- To find the current status of academic English teaching and learning problems in China.

- To find the possible solutions to the problems based on previous research works. 
- To find the possible suggestions to enhance the level of academic English teaching and learning in China.

\section{The significance of the Study}

This research is to give an idea of the current status of AE language from social, political, educational and economic aspects. The study will give an analysis and overview of Chinese English at an academic level. With respect to this perspective, Chinese English will be seen from different aspects then results can assist in developing new teaching techniques and ESL pedagogy at an academic level.

\section{LITERATURE REVIEW}

\section{Kachru's Model}

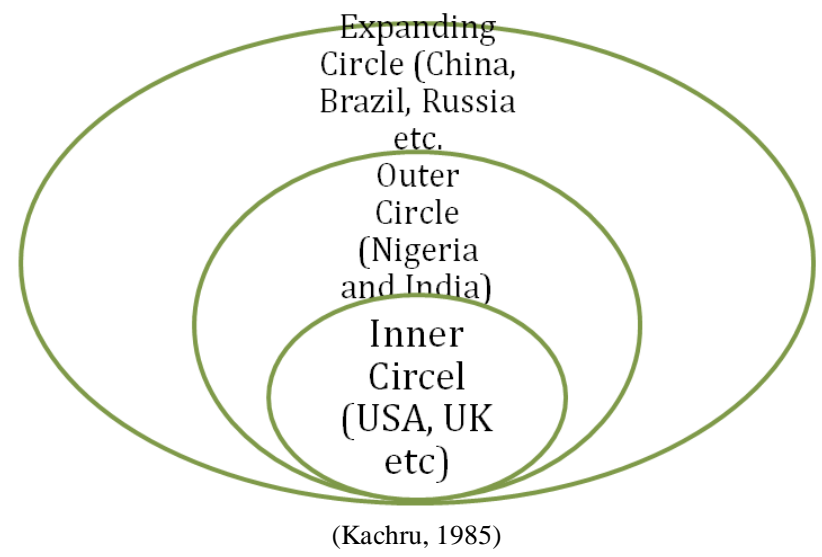

There are three terms used to speak English in three circles; in outer circle as a second language, in the inner circle as a native language and in expanding circle as a foreign language (Chen, 2015). The inner circle is based in UK, USA, Australia, Canada and New Zealand. The outer circle involves Bangladesh, Malaysia, Singapore, Pakistan, India, Sri Lanka, Kenya, Tanzania, Zambia, Ghana, and the Philippines. The last expanding circle includes China, Japan, Nepal, Indonesia, Taiwan, Korea, Israel, Zimbabwe, Saudi Arabia, Egypt, and USSR. This model is given by Kachru (1985). China is included in the expanding circle and the English Language is considered as a foreign language in this country due to which Chinese people find it so difficult. Chinese English involves a variety of mixed elements including vocabulary, Chinese culture relevant aspects, pronunciation and sentence structure. Chinese speakers used this English as a bilingual and English in both contexts.

Crystal (2012), discussed the varieties of World English languages which are spoken almost in 75 territories as a first or second language. In addition to this, it is very difficult to obtain the number because the varieties are still growing in the world. Kachru et al. (2009), stated that new Englishes are continuously emerging. In future, it would be challenging to define a world language because Englishes will diverge into unintelligible languages. There is a history of the existence of English language in China. In 1949, China opened to the outside of the world when British English was dominant as a foreign language, however Russian was adopted for some time. The first reason was that the Soviet Union had influenced Chinese education and had British English features. The second reason was that US and China had less contact while the US became politically, socially and economically strong. The third reason was the number of British people in the Chinese editorial field.

In the 1980s, when Chinese industries have become strong and successfully developed, the need for English has been stimulated. Due to development in modernization of industries, trade perspectives, globalization and international reforms, China felt the need to learn AE language for their international relations. A large number of people began to learn American English because of the gradually influence by American entertainment industry including internet, radios, movies, and music. From the history of the development of English in China, it was concluded that social and political contexts have brought English in China (Chen, 2015). Moreover, over 300 million people are learning and using English and this number is continuously increasing according to the requirement of national policy and other relevant policies. For example, English examinations are compulsory for entering universities, schools, and colleges. There are many other motivations to learn AE in China such as acquiring well-paid jobs more easily than those who know Chinese only. Furthermore, English has become essential for those top-ranking universities with bilingual teaching method for science and engineering subjects. Summing up this all means English is growing rapidly in China as well as people are going to international universities to get proficiency in English.

In the Chinese society, there is a strong need to get AE Language training for Chinese students due to increasing migration to oversea institutions for study. According to a research of British Council, AE language training has increased and are the greatest among all the Asian countries ( $\mathrm{Li}$, Chen, and Duanmu, 2010). Currently, the English Language has witnessed substantial growth in China due to political and social reforms. In a report, it has been revealed that there are almost 400 million learners of AE language in China due to increases in English language teaching in 
schools and colleges. According to China Daily (2010), the importance of AE language in China has increased after the policy reforms which has opened China to the outside world. This has helped the country to enhance trade relationships and has also helped students in the future who have planned to study abroad. However, due to lack of English language learning, it has been found that the Chinese students have faced difficulties in international universities because of lacking proficiency in academic English (Yang and Duan, 2016).

\section{Academic English Learning and Teaching}

It is important to understand English for the academic purposes because it has been used extensively by the book writers, researchers, and websites. Most of the academic materials of all subjects are available in the English language on the websites and can only used be used by someone who has a command on the English language (Crystal, 2012). In addition to the availability of academic material in English language, there is another point that makes it necessary for the students to learn AE. For most of the academic degrees internationally, the universities require the students to complete their own research papers as a requirement of degree completion and to publish them in an international journal. The AE language is the first and most important requirement of the journals for a paper for acceptance. The international journals accept the journals written in English language only (Wiley Online Library, 2018).

In learning the $\mathrm{AE}$ language, the teachers play a vital role by explaining the grammar rules and analyzing the students' learning outcomes. In addition to the importance of AE language at international level, knowing English as a language has also gained importance globally. There have been a lot of complaints from the teachers and students that the opportunities available to learn English are not enough in their country (Gil, 2008).

The trends of English language teaching began with the formation of Peoples Republic of China back in 1949. Since then Chinese education has been faced with a situation of ups and downs in learning $\mathrm{AE}$ as a foreign language. With an increase in the demand of English language, the commitment of both teachers and learners has increased. According to Cortazzi and Jin (1996), the number of English language teachers and students is greater in China than in any other countries. According to Hildebrandt and Liu (1991), the political, economic, and social forces play a crucial role in the expansion of AE Language teaching and learning. Apart from these things, it has been found that there are many problems related to AE language teaching in China creating challenges.

\section{Why is Learning AE important for Chinese Students?}

English is an international language which needs to be learned with proficiency for getting higher education in many countries. However in most countries, the increasing trend of learning $\mathrm{AE}$ as a second language is significant. In countries like China where educational institutions follow the Chinese language for graduation, learning AE is very difficult for students (Gorsuch, 2011). Students who are going abroad for their higher education have faced many issues during class time to understand teacher's accent and do not score high as expected. There are many personal learning problems due to which Chinese people are unable to learn the English Language. The demand for the English language in China has increased with the globalization of Chinese economy. The globalization of the economy demands the good communication. China has been focusing on promoting the English language after policies and reforms to communicate with other countries in the world. The English Language plays a very important role in all fields including education, business, and media. As an acceptance of the importance of AE language, the Chinese Ministry of Education has come out with policies regarding the English tests and the status of English learning changing since then (Zhang, 2017).

With an increase in the use of English language in academic institutions globally, the importance of learning AE as an language has also increased. Also, the number of Chinese students pursuing further education abroad in well-developed countries i.e., UK and USA has increased. According to a research of British Council, the number of immigrants to the well-developed countries will reach almost 5.8 million by the year 2020. The number of immigrants from China is the largest of the Asian countries (Li, Chen, and Duanmu, 2010). A very large number of Chinese students have migrated to the USA in the past decade. However, it has been found that Chinese students have been facing difficulties in international universities due to lack of proficiency in AE (Yang and Duan, 2016).

Before going for education in the international universities, Chinese students are required to pass the English language tests i.e. TOFEL, IELTS etc that analyze the students' capabilities related to their proficiency in the English language. Chinese students have reported multiple problems related to English learning and speaking. Most of the students reported the scenario to be frustrating for them (Edward, Ran, and Li, 2007).

Students have been facing this problem because AE they have learned from their country is not good enough to compete in the international institutions. From a academic point of view, learning AE means learning the correct sentence structure and tenses of the AE language (Schunk, 2012). It has become essential for Chinese students to learn $\mathrm{AE}$ because as it has been affecting their education performance at international institutions. According to Wardlow and Johnson (1999), learning courses in English for students with lack of proficiency in English speaking can affect their educational performance. Li et al., (2010) investigated the relationship between the proficiency in English and academic achievement of Chinese students in US university. It has been found that the lack of proficiency in academic language likely affected negatively on the Chinese students as English is not their major and there is limitied proficiency in their English speaking and understanding. There have been many studies focused on highlighting the issues faced by the Chinese students during their study in an international university (Gu and Schweisfurth, 2006; Turner, 2006a; Ding, 2009; Tian and Lowe, 2009).

American and British English language have powerful impact on English teaching in Chinese education sector in 
terms of teaching methods, curriculum design, textbooks, and assessment. For instance, English translation in English teaching system is not enough to achieve the goal of making students able to speak English fluently. In previous studies, various authors discussed that English teaching methods should be different from other methods which are adopted in other countries including those in an inner and outer circle because Chinese are in expanding circle where English is neither a second and nor a native language. In addition to this, Chinese cultural environment is not good for practicing English because there are limited people who speak English. Meanwhile, English curricula designs should not be adopted in Chinese educational institutions because Chinese learning abilities are different from those from countries involved in the inner circle. In addition to this, curricula design should also involve speaking and listening courses while previous courses involve only writing and reading courses.

\section{Current Status of Academic English teaching and learning in China}

During the past decade, a tremendous shift has been seen in the status of AE language in China as it seems to have replace the Russian language. As a result of the official policy of the government of China in the National Education System, the importance of AE language in China has increased (Adamson, 2002). Considering the new policy reforms, the Chinese government has giving increased attention to recovering the position of English language teaching. In addition, Chinese parents are also aware of the importance of AE language now being advertised by the Chinese government. After this reform, there are so many institutions opened in China to meet the demands of parents. According to a report, the number of such institutions in China has reached 50,000 (Zhang, 2017).

In 1978, the Chinese government adopted opening up policy and reform due to which English education has entered into China (Li and Moreira, 2009). With respect to population, Chinese English learners are largest in the world. As stated by Bolton and Graddol (2012), since 2010 more than 400 million people have been involved in English learning. It is compulsory at a primary level until college graduation to learn English. The growth level has not reached the maturity level but the Chinese government has taken powerful actions to implement AE learning and teaching effective actions in the education department. Despite all the efforts of the government, college learning level is not sufficient to improve student's English listening and speaking and does not foster their interests to learn English with proficiency. Due to which new methods and techniques are needed to develop and monitor the Chinese Education sector (Chen, 2015).

Additionally, there is a lack of policies by the government for promoting the English language. The Chinese people consider it of no importance that they learn English. In their opinion, it is completely alright because foreigners also don't know the Chinese language. Currently, the government of China has made some policies for the improvement of AE to overcome the problems Chinese students have been facing in Education and the working field. However, the impact of poor policies of the past still affects the Chinese system. The trends seemed to be changed very quickly for the education of foreign language after the formation of P.R.C. The policies related to foreign language in China changed very quickly between the 1950s and 1990s. According to Gil and Adamson (2011), in the era of 1950s, the Russian language was promoted in China and the English teachers were also changed to Russian teachers. Later in the early 1960s, the policies were changed and the English teachers again got some value and replaced the Russian teachers. Again from the late 1960s till the half of seventies, the English Language was banned and restricted in the educational institutions. The whole discussion shows that there is an improvement in Chinese learning by the Chinese students but there still needs to be development as students have been facing challenges in the foreign countries.

\section{The Development and motivation for Using Chinese as a Second Language}

According to Cook (2016), most people globally learn a second language other than their national language. This generates an issue on how the second language can be learned effectively. Generally, in most of the countries, the second language is taught as a separate subject in the classrooms. According to Lyster \& Ballinger, (2011), in this process, the primary concern is to teach the students a second language with the help of their first language. This helps the teachers to communicate the second language to the students in a very meaningful way (Genesee, 2006). The effectiveness of such programs related to the learning of English has been supported by many hypotheses of English learning. According to (Krashen, 1982), when the teachers deliver the content in the English, the learners certainly gives the content more attention which results in better learning of English. It has been observed that the students learn more about English through interacting with their peers and teachers. This is because it allows a high level of interaction due to better input and feedback from the peers and teachers about the language. According to Long (2005), these comprehensive scenarios help the individuals in learning the English language. Considering all these points, it will be possible for the students to use the English language as a mode of integration in the classrooms and in the outside world.

\section{Methodology}

The study adopts both qualitative and quantitative data analysis and also uses both primary and secondary data. The primary data was collected using the past literature, case studies, and surveys. The secondary data was collected using a questionnaire that was distributed among 330 respondents consisting of Chinese students and teachers.

\section{Selecting the past studies for qualitative analysis}

In terms of both qualitative and quantitative approaches for the analysis of the topic, the first task was to select the appropriate studies to support the data analysis and discussion. This study focused to get the most recent research as the 
purpose of the study to evaluate the current situation of AE language learning in China and the reforms that are required. For this, the study accesses the reviewed journals and dissertations to evaluate the difficulties of Chinese in the field of English. The study has recognized and reviewed the studies published in 1980 or afterward. The previous studies are identified and reviewed to identify if they are appropriate enough to be included in the meta-analysis of this study. During the identification process, the studies with irrelevant data were avoided.

\section{Data Collection and Techniques}

In addition to the qualitative data analysis, the study also includes the quantitative data analysis. In this study, we collected primary data through the questionnaire. Initially, the questionnaires were distributed among 330 respondents. Total 315 complete questionnaires in all aspects were received back that have been included in the study to do a quantitative analysis. The samples for the data collection purposes were selected randomly. The respondents made sure about the secrecy of their responses. Regression and correlation analysis was used to analyze the relationship between variables. Given below is the questionnaire distributed among the respondents to collect responses.

\section{RESUlts AND ANALYSIS}

\section{Results}

To estimate the effects of poor English teaching facilities (PETF), worse intelligibility (WI), grammatical issues (GI), poor communication skills (PCS), and language complexity (LC) on the challenges (C) faced by the Chinese students, this study estimates the reliability, regression, and correlation.

TABLE 1

RELIABILITY ANALYSIS

\begin{tabular}{ll}
\hline Cronbach's Alpha & N of Items \\
\hline .832 & 6 \\
\hline
\end{tabular}

To test the reliability of the questionnaire, Cronbach alpha test is used. According to Zacks (2012), the range of reliability is decided according to the measures used in the study. According to Ellis (2013), the value of Cronbach alpha more than 0.7 shows the reliability of the variables. In this study, the Cronbach alpha is used to check the reliability of variables included in this study.

\section{Correlation Analysis}

The Pearson correlation test is estimated using the SPSS software to analyze the relationship between the variables included in this study. If the P-value of the correlation will be less than or equal to 0.05 , this means that there is a significant relationship and a p-value less than or equal to 0.01 shows a highly significant relationship. The coefficient of correlation shows the intensity of the relationship between two variables and a value of more than 0.80 can generate the problem of multicollinearity. According to Tabachnick and Fidell (2001), the intensity and trend of relationship between two variables can be estimated through the correlation analysis.

The degree, trend, significance, and strength of the bivariate relation between all the variables can be estimated using Pearson correlation (Sekaran, 2003). The Person correlation is used to determine the relationship between two variables and the value of correlation coefficient lies between +1.0 and -1.0 . The +1.0 value means that association is perfectly positive and the value -1.0 means that the relationship is perfectly negative. The absence of any relationship is shown by 0 value of the correlation coefficient.

TABLE 2

CORRELATIONS ANALYSIS

\begin{tabular}{|c|c|c|c|c|c|c|c|}
\hline & & PETF & WI & GI & PCS & $\mathrm{LC}$ & $\mathrm{C}$ \\
\hline \multirow{2}{*}{ PETCF } & Pearson Correlation & 1 & $.664^{* * 4}$ & $.120^{*}$ & $.245^{* *}$ & $.336^{* * \pi}$ & $.389^{* * *}$ \\
\hline & Sig. (2-tailed) & .000 & .000 & .034 & .000 & .000 & .000 \\
\hline \multirow{2}{*}{ WI } & Pearson Correlation & $.664^{* *}$ & 1 & $.329^{* *}$ & $.350^{* *}$ & $.531^{* *}$ & $.613^{* *}$ \\
\hline & Sig. (2-tailed) & .000 & .000 & .000 & .000 & .000 & .000 \\
\hline \multirow{2}{*}{ GI } & Pearson Correlation & $.120^{*}$ & $.329^{* *}$ & 1 & $.624^{* *}$ & $.501^{* *}$ & $.622^{* *}$ \\
\hline & Sig. (2-tailed) & .034 & .000 & .000 & .000 & .000 & .000 \\
\hline \multirow{2}{*}{ PCS } & Pearson Correlation & $.245^{* *}$ & $.350^{* *}$ & $.624^{* *}$ & 1 & $.542^{* *}$ & $.493^{* *}$ \\
\hline & Sig. (2-tailed) & .000 & .000 & .000 & .000 & .000 & .000 \\
\hline \multirow{2}{*}{$\mathrm{LC}$} & Pearson Correlation & $.336^{* * *}$ & $.531^{* *}$ & $.501^{* *}$ & $.542^{* *}$ & 1 & $.538^{* *}$ \\
\hline & Sig. (2-tailed) & .000 & .000 & .000 & .000 & .000 & .000 \\
\hline \multirow{2}{*}{$\mathrm{C}$} & Pearson Correlation & $.389^{* *}$ & $.613^{* *}$ & $.622^{* *}$ & $.493^{* *}$ & $.538^{* *}$ & 1 \\
\hline & Sig. (2-tailed) & .000 & .000 & .000 & .000 & .000 & .000 \\
\hline
\end{tabular}

The challenges are found to have positive and highly significant relationship with all the independent variables. The correlation coefficient between Poor English Teaching Facilities and Challenges is .38 with P-value less than 0.01 means there is positive and highly significant relationship between Poor AE Teaching Facilities and Challenges. This means that the Poor English Teaching Facilities will increase the challenges for Chinese students in learning English language. The correlation coefficient between Worse Intelligibility and Challenges is .61 with P-value less than 0.01 means there is positive and highly significant relationship between Worse Intelligibility and Challenges. This shows that the poor intelligibility of Chinese students will increase problems for them in learning English Language. The 
correlation coefficient between Grammatical Issues and Challenges is .62 with P-value less than 0.01 means there is positive and highly significant relationship between Grammatical Issues and Challenges. This shows that the Grammar of Chinese students will increase problems for them in learning English Language. The correlation coefficient between poor communication skills and Challenges is .49 with P-value less than 0.01 means there is positive and highly significant relationship between Grammatical Issues and Challenges. This means that the students with the poor communication will face more challenges in AE language learning. Lastly, the correlation coefficient between language complexity and Challenges is .53 with P-value less than 0.01 means there is positive and highly significant relationship between language complexity and Challenges. This clearly means that if the students will have a language complexity, it will be difficult for them to learn AE Language.

All the independent variables included in the student are also positively and highly significantly correlated with each other except the grammatical issues and poor teaching facilities that are positive but significant at 0.05 levels. The significant and positive relationship of the independent variables shows that any of one of these problems can generate the other problems as well and then can lead to problems in learning the AE.

\section{Regression Analysis}

The regression model is used to estimate the relationship between dependent and independent variables. SPSS software was used to estimate the regression model. Primary data was collected through the questionnaire for the Chinese students in learning the AE.This study involves 5 independent and one dependent variable. In the table below, is a regression analysis to find the impact of poor English teaching facilities, worse intelligibility, grammatical issues, poor communication skills, and language complexity on Challenges faced by Chinese students in learning AE.

TABLE 3

REGRESSION ANALYSIS

\begin{tabular}{lllll}
\hline \multicolumn{4}{c}{ REGRESSION ANALYSIS } \\
\hline Model & R & R Square & Adjusted R Square & Std. Error of the Estimate \\
\hline 1 & $.763^{\mathrm{a}}$ & .582 & .575 & .58206 \\
\hline
\end{tabular}

The value of $\mathrm{R}$ in this study is .76 which shows the total variations in poor English teaching facilities, worse intelligibility, grammatical issues, poor communication skills, and language complexity. R square in the model is called coefficient of determination and shows the fitness of the regression model to the regression line (Zikmund et al., 2013). The value of $\mathrm{R}$ square in this model is .582 and shows that the total variations in the challenges faced by the Chinese students are due to poor English teaching facilities, worse intelligibility, grammatical issues, poor communication skills, and language complexity. The value of adjusted R Square in the model shows the degree of the fitness of the variables. according to Munir et al., (2013), with an increase in the number of variables in the study, the value of adjusted $\mathrm{R}$ square decreases. The closeness between the $\mathrm{R}$ square and adjusted $\mathrm{R}$ Square shows the presence of useful variables in the study. The value of adjusted $R$ Square in this study is .575 close to the value of $R$ Square which means that the independent variables involved in the study are true determinants of the dependent variable.

TABLE 4:

REGRESSION ANOVA ${ }^{\mathrm{a}}$

\begin{tabular}{lllllll}
\hline Model & & Sum of Squares & df & Mean Square & F & Sig. \\
\hline \multirow{3}{*}{1} & Regression & 145.497 & 5 & 29.099 & 85.891 & $.000^{\mathrm{b}}$ \\
& Residual & 104.688 & 309 & .339 & & \\
\hline
\end{tabular}

The value of F-Statistics in the model shows the significance of the overall model. The value of F-statistics can be compared with the standard significance value. A value of significance below 0.05 shows the significance of the model. The value of significance of the above model is 0.000 which means that the impact of poor English teaching facilities, worse intelligibility, grammatical issues, poor communication skills, and language complexity on Challenges faced by Chinese student is highly significant.

TABLE 5:

REGRESSION COEFFICIENTS ${ }^{\mathrm{a}}$

\begin{tabular}{|c|c|c|c|c|c|c|}
\hline \multirow{2}{*}{\multicolumn{2}{|c|}{ Model }} & \multicolumn{2}{|c|}{ Unstandardized Coefficients } & \multirow{2}{*}{$\begin{array}{l}\text { Standardized Coefficients } \\
\text { Beta }\end{array}$} & \multirow{2}{*}{$\mathrm{t}$} & \multirow{2}{*}{ Sig. } \\
\hline & & $\mathrm{B}$ & Std. Error & & & \\
\hline \multirow{6}{*}{1} & Constant & .737 & .200 & & 3.685 & .000 \\
\hline & PETF & .076 & .044 & .086 & 1.739 & .038 \\
\hline & WI & .031 & .045 & .035 & .698 & .048 \\
\hline & GI & .384 & .045 & .425 & 8.599 & .000 \\
\hline & PCS & .329 & .048 & .384 & 6.922 & .000 \\
\hline & $\mathrm{LC}$ & .037 & .040 & .046 & .920 & .035 \\
\hline
\end{tabular}

According to Saunders (2011), the B in the model is unstandardized coefficient and shows the change in the Challenges with one unit change in poor English teaching facilities, worse intelligibility, grammatical issues, poor communication skills, and language complexity. The value of the constant in the model in .737 and this shows the average value of challenges faced by the Chinese students when poor English teaching facilities, worse intelligibility, 
grammatical issues, poor communication skills, and language complexity will be zero.

The B value of poor English teaching facilities is .07 with a significance value $.03<.05$ means that one unit increase in poor teaching facilities will increase the challenges by .07 units. The B value of worse intelligibly is .03 with a significance value of $.04<.05$ means that with one unit increase in worse intelligibility, the challenges will increase by .07 units. The B value of grammatical issues is .34 with a significance value of $.00<.01$ means that one unit increase in grammatical issues will increase the challenges by .34 units. The B value of poor communication skills is .32 with a significance value of $.00<.01$ means that with one unit increase in poor communication skills there be .32 unit increase in the challenges. The B value of language complexity is .03 with a significance value $.03<.05$ means that one unit increase in language complexity will increase the challenges by .03 units.

\section{DISCUSSION}

The results show that the poor English teaching facilities in China are one of the main causes that create challenges for Chinese students in learning AE. The problem has been explained by many studies considering different factors. There is lack of AE teachers in China and this is due to lacking English speaking practice on the routine basis. The opportunities to learn $\mathrm{AE}$ are limited resulting in reduced demand for English teachers. The available English teachers go to the bigger cities to get higher paid jobs and this creates a gap for English language teachers (Gil, 2008). One of the resources they have beenunderutilized is their own students studying in foreign countries. The reason for the shortage of teachers can be related to the underutilization of the English teacher resources produced in the form of university graduates or postgraduates from the UK or any other international countries. The underutilization means that they can't get the equal salaries as paid to the English teachers from foreign countries; therefore, they prefer to stay abroad and get higher paying jobs. They can be proven as a gem for the Chinese students, but most of the times this is wasted.

The students also suffer from the teaching styles of the English teachers. AE language teachers while teaching mostly focus on accent and try to speak in speed and this creates the problem for the Chinese students (Yang, 2017). Holmes (2004) investigates the issues by collecting the data from 13 Chinese students studying in New Zealand and found that the learning abilities of students was affected by the speed of their lecturer. It has been observed that the students have been facing a problem because the English speed they are used to listening to consists of 160-180 words per minute, but, the normal speed of speaking English in international universities generally lies between 220-240 words per minute (Yang, 2017). In addition to speed, the accent of teachers is also found to be a reason behind the difficulties faced by Chinese students. According to Shi (2007), due to differences in accent, students find it difficult to understand their teachers and peers and hence difficult to communicate with them.

Another possible resource for English language learning is by approaching the foreign teachers. This resource, however, is found to be costly in case of China due to high salary demands. Due to the very high cost, it is not possible for the Chinese government to approach a large number of foreign teachers. As an alternative to foreign teachers, the local native teachers can be approached and can be utilized after a short-term training (Rao and Yuan, 2016). They seemed to be a better option because the student may face problems in understanding the accent of foreigner teachers. The situation, sometimes, leads to serious issues when the students fail to learn the AE even from a high paid teacher.

The results of the study found that the worse intelligibility is another major cause that creates challenges for the Chinese students. The reason for finding difficulty in AE learning is the lack of spoken intelligibility and unfamiliarity with the correct English accent. The results are consistent with Yang and Yuen (2014), which states that the problem of unfamiliarity with accent further leads to lack of proficiency in Chinese English language learners. Also, it has been found that the Chinese students hold the worse spoken intelligibility of the English language as they try to understand English in Chinese accent (Harding, 2012). According to research by Yang and Yuen (2014), this problem occurs due to the inefficiency of teachers in teaching AE. Chinese teachers also use Chinese English rather than the Standard English during the training sessions. This makes the students confident for the time being but then they face difficulties when communicating with the outside world. This problem can be solved only by practicing the English language to enhance the spoken skills. This will increase the communication and will then increase the English learning capabilities (Jin and Liu, 2014).

According to the results of the study, grammatical issues are the important factors that lead to generating Challenges for the Chinese students in learning the language. In support of the results, Huang (2005), discussed that native Chinese speakers find the English language difficult to learn such as sounds and grammar issues. Compared to English, in the Chinese language, there are limited numbers of sounds one needs to learn. In Chinese, a single word is used to convey the whole message sometimes, and compared to this; the English language has so many words and further include many characters. Another problem is the poor grammar of Chinese people. Bao and Sun (2010) focused on the grammatical issues Chinese people have in learning English as an academic language. The basics of Chinese language are entirely different from the English language and don't include tenses or any grammatical aspects. For the Chinese students, learning English as an academic language means learning all the new rules of the grammar and tenses. Vocabulary also seems to create the problem for the Chinese students. New words used by the teachers and unknown expressions are likely to create the problem for the students. The problem related to vocabulary likely occurs in case of incompetency of the students' existing vocabulary knowledge of the English language. It has been observed that the students feel uncomfortable in the classrooms when they come across unfamiliar words and also when they can't find the words to 
communicate their point of view (Yang and Yuen, 2014).

The poor communication skills are also found to create issues for the Chinese students in learning the English language. As stated by Holmes (2004), the oral communication problems, the Chinese students have reported are mainly due to inablilty to understand the teacher's viewpoint and at the same time they feel uncomfortable in asking questions as they have no proficiency of the English language. The Chinese students in the Chinese education environment are reported to be restricted to a lecture dominated environment that doesn't allow them to contribute in the classroom. Contrary to this, the American universities have developed an environment of interacting with the students during the lecture to enhance their understanding of the topic through a question-answer session. The Chinese students seem to face difficulties in this environment. The only thing suggested, in this case, is to focus on the English academic learning of Chinese students.

Lastly, the results have found that the complexity of English language compared to Chinese is another main cause of hurdles in English language learning. As stated by Huang (2008), some of the problems and challenges the students face in learning English are that the English language has too many sounds and words. According to Harwell, Chinese have limited syllables, exactly 412 only. It is very easy for English speakers to learn Chinese because there are few new sounds. On the other hand, when Chinese students learn English they are confronted with a complete suite of sounds with which they are not familiar. The reason for a huge number of sounds is that words have been taken from Dutch, French, German and Latin to form a set of vocabulary in the English language. The second problem is spelling of english. This is due to Chinese students lack of understanding the complexity in sentences. There are many apps and computer software which enable the students to learn English but those are also not programmed to understand native speakers' communication style. These apps and software translate the simple sentence for developing understanding (Harwell, 2016). Moreover, Chinese are confused about silent words for example; they pronounce "Know" as "keh-Now" and "Damn" as "Dam". In addition to this, they cannot differentiate Qu from Qw and Gu from Gw. The third problem is related to grammar which is discussed above by Aiguo (2007). The fourth problem is tenses which are a new concept for students in China. Finally, it is evaluated that the Chinese language does not have rules and regulation that's why it is easy to learn. However, English language rules related to tenses, vocabulary and pronunciation make it difficult for them to learn.

\section{CONCLUSION}

The empirical evidence of the study indicates that there are multiple factors that have been generating challenges for Chinese students in learning the English language in China It has been observed from the literature that the policy reforms have been implemented to improve the English language teaching and learning. The government of China has been focusing on bringing policy reforms and has directed the Chinese Education System about the improvements that are needed. The teachers, students, and even the parents of the students are found to be very motivated towards learning English language as the Chinese people are lagging behind due to the English language when it comes to interacting with the outside world.

It has been found that the English teaching facilities in China are relatively poor. It was found there is a lack of local English teachers in China and foreign teachers have been found to be too costly for the country. Additionally, the teaching style of local English teachers is also creating issues. Lack of intelligibility also seems to create a problem for the Chinese students. This means that the poor English accent unfamiliarity with English accent doesn't allow the Chinese students to become quick English learners. Chinese students are having more grammatical issues at a greater extent in terms of tenses, pronunciation, and vocabulary. The involvement of tenses in the English language compared to Chinese is a big issue. Additionally, the vocabulary of English language is much more than the Chinese language making it a difficult language to learn.

The poor communications skills are found to create challenges as Chinese students who want to study abroad face many difficulties in interacting with peers and teachers. The complexity of English Language is found to be the main cause of poor AE learning of Chinese students. There are so many sounds and words in the English language and there are so many other requirements for completing a sentence. All these problems have made it difficult for the Chinese students to learn the English language.

\section{IMPLICATIONS}

To solve the problems Chinese students are facing in AE learning, some policy reforms are recommended for the Chinese system. The Ministry of Education is suggested to take strict decision related to English language testing of students as a condition for the entry in college or university. The government has made some policies about this and included a English component with Math and Chinese test to get admission in the college or university. However, the process needs to be stricter to solve the problem of students in the future (Bolton and Graddol, 2012).

The government of China is suggested to introduce new programs related to English language learning and teaching. In China, a 9-year program has been introduced recently and according to this program, the English language learning will be completed in 9 levels. It is expected to change the style of teaching completely and will also give importance to the grammar and vocabulary development. This new program will help the ability of Chinese students to use the 
English language in their daily lives and will also help them to increase their communication abilities. The program will help Chinese students get proficiency in English to help them in understanding their courses and doing their own research work. What needs to be done now regarding this is to make sure that the level 9 should be completed with the high standards to ensure the better state of students related to AE (Lin, 2002).

The government also needs to make policies to enhance the reading abilities of the students. It is necessary to increase the reading abilities as well because most of the study material in form of books and online material is available in English language. This requires the students to have an ability to read the English language easily. Regarding this, it should be targeted that the students can read English fluently in order to communicate and to express their opinion (Lin, 2002). Following all these suggestions, policies, and ways, it can be possible to solve the problem of $\mathrm{AE}$ learning issues at the national level and in international education institutions.

\section{ACKNOWLEDGEMENTS}

This study is sponsored by Northwest A\&F University Research Project (Grant No.2015RWYB29)

\section{REFERENCES}

[1] Adamson, B. (2002). Barbarian as a foreign language: English in China's schools. World Englishes, 21(2), 231-243.

[2] Aiguo, W. (2007). Teaching aviation English in the Chinese context: Developing ESP theory in a non-English speaking country. English for Specific Purposes, 26(1), 121-128.

[3] Arrighi, G. (2007). Adam Smith in Beijing (Vol. 389). London: Verso.

[4] Bao, J., \& Sun, J. (2010). English grammatical problems of Chinese undergraduate students. English Language Teaching, 3(2), 48-53.

[5] Bo Li, T., \& Moreira, G. (2009). Learning English in corporate China. English Today, 25(3), 41-48.

[6] Bolton, K., \& Graddol, D. (2012). English in China today: The current popularity of English in China is unprecedented, and has been fueled by the recent political and social development of Chinese society. English Today, 28(3), 3-9.

[7] Chen, H., \& Chen, H. (2015). The influence of world English's on Chinese English and English teaching in college. Journal of Organometallic Chemistry, 192(1), 1-15.

[8] Cook, V. (2016). Second language learning and language teaching. Abingdon: Routledge.

[9] Cortazzi, M., \& Jin, L. (1996c) Cultures of Learning: Language Classrooms in China in H. Coleman (ed.) Society and the Language Classroom, Cambridge: CUP pp.169-206.

[10] Crystal, D. (2012). English as a global language. Cambridge: Cambridge university press.

[11] Ding, H. (2009). East meets West: Chinese students making sense of their cultural identity in London. Changing English, 16(3), 313-321.

[12] Edwards, V., Ran, A., \& Li, D. (2007). Uneven playing field or falling standards?: Chinese students' competence in English. Race Ethnicity and Education, 10(4), 387-400.

[13] Ellis, J. L. (2013). A standard for test reliability in group research. Behavior Research Methods, 45(1), 16-24.

[14] Genesee, F. (2006). Educating English language learners: A synthesis of research evidence. Cambridge: Cambridge University Press.

[15] Gil, J. (2008). China's English language environment. English Language Teaching, 1(1), 3-9.

[16] Gil, J., \& Adamson, B. (2011). The English language in mainland China: A sociolinguistic profile. In A. Feng (Ed.), English language education across greater China (pp.23-45). Bristol, UK: Multilingual Matters.

[17] Gorsuch, G. (2011). Exporting English pronunciation from China: the communication needs of young Chinese scientists as teachers in higher education abroad. Forum on Public Policy Online, ERIC. Available: http://forumonpublicpolicy.com/vol2011no3/archive/gorsuch.pdf. Retrieved on Jun 15, 2018.

[18] Gu, Q., \& Schweisfurth, M. (2006). Who adapts? Beyond cultural models of 'the' Chinese learner. Language, Culture and Curriculum, 19(1), 74-89.

[19] Harding, L. (2012). Accent, Listening Assessment and the Potential for a Shared-L1 Advantage: A DIF Perspective. Language Testing, 29(2), 163-180.

[20] Hildebrandt, T. H., \& Liu, W. (1993). Optical recognition of handwritten Chinese characters: advances since 1980. Pattern Recognition, 26(2), 205-225.

[21] Holmes, P. (2004). Negotiating differences in learning and intercultural communication: Ethnic Chinese students in a New Zealand university. Business Communication Quarterly, 67(3), 294-307.

[22] Huang, J. (2005). Challenges of academic listening in English: Reports by Chinese students. College student journal, 39(3), 553-570.

[23] Jin, S.-H., \& Liu, C. (2014). Intelligibility of American English Vowels and Consonants Spoken by International Students in the United States. Journal of Speech, Language \& Hearing Research, 57(2), 583-704 122p. http://doi.org/10.1044/2014_JSLHR-H-13-0047. Retrieved on Jun 17, 2018.

[24] Kachru, B. B. (1985). Standards, codification, and sociolinguistic realism: The English language in the outer circle. In: Quirk, R. and H. Widdowson, (eds.) English in the World: Teaching and Learning the language and the literature. Cambridge: Cambridge University Press .

[25] Krashen, S. D. (1982). Child-Adult Differences in Second Language Acquisition. Series on Issues in Second Language Research. Newbury House Publishers, Inc., Rowley, MA 01969.

[26] Li, C. (2014). Development, Problems and Solutions: A Critical Review of Current Situation of College English Language Education in Mainland China. Arab World English Journal, 5(3), 291-303.

[27] Li, G., Chen, W., \& Duanmu, J. L. (2010). Determinants of international students' academic performance: A comparison 
between Chinese and other international students. Journal of Studies in International Education, 14(4), 389-405.

[28] Lin, L. (2002). English education in present-day China. Asian/Pacific Book Development, 33(2), 8-9.

[29] Liu, S. (2015). Reflections on Communicative Language Teaching and its application in China. Theory and Practice in Language Studies, (5), 1047-1052.

[30] Liu, Y. (2009). The current situation and issues of the teaching of English in China. International symposium on the teaching of English in Asia: Locating the teaching of English in Japan in Asian contexts: what we can learn from China and Korea, 21(2), 7-19.

[31] Long, M. H. (Ed.). (2005). Second language needs analysis. Cambridge: Cambridge University Press.

[32] Lyster, R., \& Ballinger, S. (2011). Content-based language teaching: Convergent concerns across divergent contexts. Language Teaching Research, 15(3), 279-288.

[33] McKay, S. L. (2002). Teaching English As An International Language: Rethinking Goals and Perspectives. New York: Oxford University Press.

[34] Munir, Y., Malik, M.E., Ahmad, S., Saleem, S. and Akbar, Z. (2013). Empirical Investigation of Indicators of Organizational Learning: Evidence from Water and Power Development Authority (WAPDA) Pakistan. Far East Journal of Psychology and Business, 10(3), pp.25-32.

[35] Pan, L., \& Block, D. (2011). English as a "global language" in China: An investigation into learners' and teachers' language beliefs. System, 39(3), 391-402.

[36] Rao, Z., \& Yuan, H. (2016). Employing native-English-speaking teachers in China: Benefits, problems and solutions: Providing native-English-speaking teachers with a local pre-service training program and adopting a team teaching approach are essential for enhancing their efficiency in the Chinese EFL context. English Today, 32(4), 12-18.

[37] Saunders, M.N. (2011). Research methods for business students. (5th edition). India: Pearson Education India.

[38] Schunk, D. H. (2012). Learning theories an educational perspective sixth edition. London: Pearson.

[39] Seber, G. A., \& Lee, A. J. (2012). Linear regression analysis (Vol. 936). New Jersey: John Wiley \& Sons.

[40] Sekaran, U., \&Bougie, R. (2016). Research methods for business: A skill building approach. New Jersey: John Wiley \& Sons.

[41] Shi, Z. (2007). Learning in a different language: A multiple case study of Chinese graduate students' classroom experiences at University of Victoria (Unpublished master's thesis). University of Victoria, Victoria, Canada.

[42] Tabachnick, B.G. \& Fidell, L.S. (2001). Using Multivariate Statistics. (4th edition). New York: Harper Collins College Publishers.

[43] Tian, M., \& Lowe, J. (2009). Existentialist internationalisation and the Chinese student experience in English universities. Compare, 39(5), 659-676.

[44] Turner, Y. (2006). Chinese students in a UK business school: Hearing the student voice in reflective teaching and learning practice. Higher Education Quarterly, 60(1), 27-51.

[45] Wardlow, G. W., \& Johnson, D. M. (1999). Levels of teaching skills and interest in teaching improvement as perceived by faculty in a land-grant college of agriculture. Journal of Agricultural Education, 40, 47-56.

[46] Wiley Online Library. (2018). International Journal of Language \& Communication Disorders. Retrieved 12 February 2018. From http://onlinelibrary.wiley.com/journal/10.1111/\%28ISSN\%291460-6984/homepage/ForAuthors.html.

[47] Yang, C. (2017). Problems Chinese International Students Face during Academic Adaptation in English-speaking Higher Institutions (Unpublished master's thesis). University of Victoria, Victoria, Canada.

[48] Yang, J., \& Yuen, C. K. (2014). College English Teaching Methodology and Language Planning: A Pilot Study in Hefei, China. Procedia - Social and Behavioral Sciences, 118, 495-502. http://doi.org/10.1016/j.sbspro.2014.02.068.

[49] Yang, X., \& Duan, Y. (2016). Difficulties of Chinese Students with Their Academic English: Evidence from a China-United States University Program, 45-51. http://digitalcommons.fiu.edu/cgi/viewcontent.cgi?article=1537\&context=sferc.

[50] Zacks, S. (2012). Introduction to reliability analysis: probability models and statistical methods. Berlin: Springer Science \& Business Media.

[51] Zhang, C. (2017). English in China Today and the influence of Education Reform. Retrieved 12 February 2018. From https://thewarwickeltezine.wordpress.com/2017/02/28/163/.

[52] Zikmund, W.G., Babin, B.J., Carr, J.C. and Griffin, M. (2013). Business research methods. Boston: Cengage Learning.

Huijuan Wang was born in Shaanxi, China, in 1981. She got M.A in applied linguistics and is currently a lecturer in Department of Foreign Languages, Northwest A\&F University, Shaanxi, China. Her research interests include English teaching and learning, English public speaking.

Yufeng Zou was born in Shaanxi, China, in 1981. He is currently a lecturer in Department of Foreign Languages, Northwest A\&F University, Shaanxi, China. His research interests include English teaching and learning and corpus-driven study. 